\title{
The addition of metformin and glucagon-like peptide-1 receptor agonist or dipeptidyl-peptidase-4 inhibitor to insulin for latent autoimmune diabetes in adults
}

\author{
Sumie Moriyama • Hidekatsu Yanai
}

Received: 18 February 2013 / Accepted: 16 November 2013 /Published online: 6 December 2013

(C) Research Society for Study of Diabetes in India 2013

\section{Dear Sir,}

Latent autoimmune diabetes in adults (LADA) is considered to be a form of autoimmune diabetes that resembles type 1 diabetes though, with a later onset and slower progression toward absolute insulin requirement. There is no therapeutic strategy for LADA [1]. Here we report a patient with LADA, who showed increased intrinsic insulin secretion by the addition of metformin, and sitagliptin or exenatide to the insulin therapy.

A 68-year-old woman, diagnosed to have diabetes in late 40s was treated with oral hypoglycemic agents for 17 years before insulin therapy in 2009. HbA1c levels were 6-7 \% until March in 2012. Plasma glucose (520 mg/dL) and HbAlc $(11.5 \%)$ levels were high. She has been treated by using 10 , 8 and 8 units of insulin glulisine before breakfast, lunch and dinner, respectively, and 18 units of insulin glargine before breakfast. Her body weight was $66.0 \mathrm{~kg}$ and height $152.0 \mathrm{~cm}$ (BMI $\left.28.6 \mathrm{~kg} / \mathrm{m}^{2}\right)$. The titer of anti-GAD antibody was elevated $(34.0 \mathrm{U} / \mathrm{ml}$; normal, $<1.5 \mathrm{U} / \mathrm{ml})$, and her urinary C-peptide level was reduced (4.6 $\mu \mathrm{g} /$ day; normal, 29.2-167 $\mu \mathrm{g} /$ day), suggesting LADA. Because an increase of insulin dose stimulated her appetite strongly, we started her on metformin in July, 2012, which improved her blood glucose and also increased her urinary C-peptide $(22.3 \mu \mathrm{g} /$ day $)$ in November, 2012. The addition of sitagliptin ( $50 \mathrm{mg} /$ day) induced more insulin secretion (52.9 $\mu \mathrm{g} /$ day), however, could not suppress her appetite completely. Therefore, we switched from sitagliptin to exenatide (10 $\mu \mathrm{g} /$ day), which remarkably suppressed her appetite and also significantly reduced daily insulin requirement (from 42 units/day to 16 units/day), and maintained intrinsic insulin secretion $(51.2 \mu \mathrm{g} /$ day $)$.

There are no studies that evaluated metformin in patients with LADA, possibly due to potential risk for the development of lactic acidosis by metformin in patients who progress toward insulin dependency [2]. We used metformin with insulin, which improved blood glucose and increased intrinsic insulin secretion without the development of lactic acidosis. To our knowledge, our report is the first to show that the addition of GLP-1 receptor agonist and dipeptidyl-peptidase4 (DPP-4) inhibitor to insulin increased intrinsic insulin secretion in a patient with LADA.

In summary, the addition of metformin and GLP-1 receptor agonist or DPP-4 inhibitor to insulin may be a promising therapeutic option for LADA.

Conflicts of interest None

\section{References}

1. Cernea S, Buzzetti R, Pozzilli P. Beta-cell protection and therapy for latent autoimmune diabetes in adults. Diabetes Care. 2009;32: S246-52.

2. Pozzilli P, Di Mario U. Autoimmune diabetes not requiring insulin at diagnosis (latent autoimmune diabetes of the adult) definition, characterization, and potential prevention. Diabetes Care. 2001;24:1460-7.
S. Moriyama $\cdot H$. Yanai $(\bowtie)$

Department of Internal Medicine, National Center for Global Health and Medicine Kohnodai Hospital, 1-7-1 Kohnodai, Ichikawa, Chiba 272-8516, Japan

e-mail: dyanai@hospk.ncgm.go.jp 